ELORE (ISSN 1456-3010), vol. $16-1 / 2009$.

Julkaisija: Suomen Kansantietouden Tutkijain Seura ry.

[http://www.elore.fi/arkisto/1_09/art_anttonen_09.pdf]

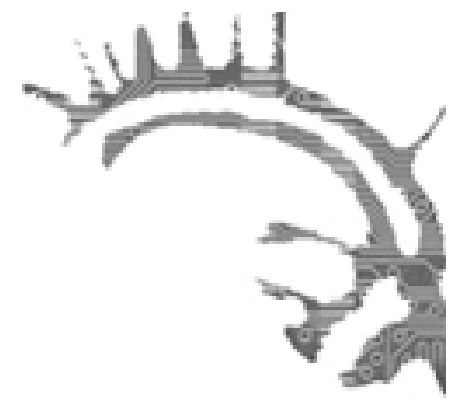

\title{
KolUMNi:
}

\section{KULTTUURIN, PERINTEEN JA PERINNÖN KYSYMYKSIÄ}

\author{
$\underline{\text { Pertti Anttonen }}$
}

Kulttuuri, perinne ja perintö ovat toisiinsa läheisesti liittyviä käsitteitä ja usein niitä käytetäänkin jokseenkin samojen asioiden ilmaisemiseksi. Kulttuuri tietojen ja taitojen ylläpitämisenä sekä niitä koskevana kompetenssina on historiallisessa ulottuvuudessaan perinnettä, joka jatkuu ja välittyy sukupolvelta toiselle kulttuurisen osaamisen perintönä. Näin perintö ja perinnön jakaminen ovat kulttuurin keskeisiä ominaisuuksia, ja kulttuurin perinnöksi määrittyminen keskeinen perinteen ominaisuus.

Tällaista moderniksi arkiajatteluksi paikannettavaa käsitesuhdetta tai paremminkin käsitevyyhtiä kulttuurin, perinteen ja perinnön välillä ei ehkä voi pitää kovin analyyttisenä, vaikka sitä esiintyy myös tieteen piirissä. Viimeisimmän Ethnologia Fennica -lehden Cultural Heritage -teeman pääkirjoituksessa todetaan, että "cultural traditions and practices passed from one generation to the next form a collective cultural heritage that guides people's behaviour'. Tämän itsestään selvältä kuulostavan aksiooman mukaan kulttuuri käytännöllisten valintojen ja toimintojen kenttänä muodostaa kulttuuriperinnön, jota koskeva tieto ja tietämys puolestaan muodostavat kulttuuri-identiteetin perustan. Identiteetti siis rakentuu perinteistä ja perinteitä on ylläpidettävä ja myös tutkittava, jotta ylipäätään voisimme toimia omina identiteettisubjekteina ihmisten kesken.

Kulttuurin, perinnön ja perinteen käsitteet samastava merkitysvyyhti palvelee enemmänkin kulttuuri- ja perinnepoliittisten näkemysten ilmaisemiseen liittyviä retorisia tarpeita kuin teoreettisesti orientoituneen tieteellisen tutkimuksen intressejä. Kulttuurin, perinteen ja perinnön käsitteiden rinnastaminen on hyödyllistä, kun halutaan ilmaista tiettyjen ajattelu- tai toimintatapojen tai niiden puitteissa kehkeytyneitten aineellisten tai aineettomien hyödykkeiden sosiaalista arvoa ja niiden historiallista jatkuvuutta. Tutkimus, jonka tarkastelun kohteena ovat juuri tällaiset merkityksenantojen prosessit, ei kuitenkaan voi rakentua käsitesuhteille, jotka ovat tutkittavan kohteen tuotteita. 
Tämän päivän konstruktivistisesta näkökulmasta käsin voidaan hyvin sanoa, ettei perinne eli traditio ole määrättyjen perinteeksi sanottujen tai luokiteltujen kulttuuri-ilmiöiden sisäinen tai sisäsyntyinen ominaisuus vaan historiallistavan, kollektivisoivan ja argumentoivan puhetavan kautta tuotettua kulttuurisen toiston nimeämistä, merkityksenantoa ja arvon määritystä. Perinne on yhtältä ennen tehdyn tai ajatellun uusintamista ja toistamista, mutta toisaalta sekä samanaikaista että jälkikäteistä uusintamisen ja toistamisen merkityksellistämistä ja mahdollistamista. Siksi perinne on keskeiseltä merkitykseltään kulttuuriseen tietoon ja taitoon sisältyvien jatkuvuuksien ja katkoksien tuottamista ja määrittämistä.

Tämä ei kuitenkaan tarkoita, että kulttuurisen välittymisen prosesseihin tai aikaan ja aikasuhteisiin sisältyvät merkitykset luotaisiin pelkästään nykyisyydessä tehtävin perinne- tai historiapoliittisin tulkinnoin. Vaikka nykyisyys tuottaa menneisyyskuvia, menneisyys ei ole vain nykyisyyden tuote. Historiaan ja aikasuhteisiin liittyvillä nimeämisen, luokittamisen ja merkityksenannon käytänteillä on samanaikaisesti oma nykyisyyksien historiansa ja toistamisen perinteensä vaikuttamassa siihen, minkälaisia perinteellisyyden merkityksiä menneisyyskuville annetaan.

Toistamisen ja toistuvuuden lisäksi perinteen käsite viittaa toistettavuuteen eli toistettavaksi tekemiseen ja toistamisen mahdollistamiseen, ja sitä kautta kulttuurin ja kulttuurituotteiden perinteellistämiseen. Perinne on argumentaatiota, jossa esitetään aikasuhteita tuottavia väitelauseita ja tehdään aikasuhteita tuottavia tekoja. Samalla tällaiset sanalliset tai ei-sanalliset väiteteot tehdään uskottaviksi ja välittymiskelpoisiksi yhtä lailla merkityksenmuodostuksen kuin toiminnallisen muodon ja rakenteen suhteen.

Perinteen käsitteellä tarkoitetaan sekä arkipuheessa että perinteentutkimuksen tieteellisessä ammattikielessä lähinnä sukupolvelta toiselle välittyvän kulttuurisen tiedon siirtymisprosessia ja niitä kulttuurisen tiedon ja osaamisen tuotteita, jotka sukupolvelta toiselle välittyvät. Perinne on tästä lähtökohdasta käsin yhtä lailla saman asian säilymistä kuin saman asian ilmentymistä uusien muotojen kautta. Jälkimmäisessä tapauksessa perinteeksi ymmärretään se ajattelutapa, diskurssi, maailmankuva, mentaliteetti tai kulttuurinen järjestelmä, joka mahdollistaa uusien muotojen syntymisen mutta joka samalla kytkee uudet muodot vanhoihin muotoihin - tai paremminkin tuottaa tulkinnallisen viitekehyksen jossa uusi näyttäytyy vanhan jatkumona. Kun perinteen käsitettä käytetään saman ilmiasun omaavan ajatuksen tai asian (esimerkiksi saman tekstiasun omaavien ilmauksien) toistumiseen ja toistamiseen, usein katsotaan että uudestaan esittämisen prosesseihin on sovellettava matemaattista kriteeriä siitä, kuinka monen toimijan, puhujan tai kertojan toimesta tietty teko tai ilmaus täytyy ilmetä, jotta voitaisiin puhua perinteestä. Esimerkiksi traditio-käsitteestä kokonaisen kirjan kirjoittaneen Edward Shilsin mukaan "at a minimum, two transmissions over three generations are required for a pattern of belief or action to be considered a tradition".

Yleensä perinteestä puhutaan vakiintunein osoittimin eli se rajautuu tarkoittamaan määrättyjä pitkän ajan kuluessa ja/tai sukupolvelta toiselle välittyneitä tai sellaisiksi katsottuja ilmiöitä, tietoja, uskomuksia, osaamisen osoituksia ja muita ajattelun ja toiminnan tapoja. Tämä on tuotekeskeinen näkökulma perinteeseen. Sen mukaisesti esimerkiksi ajatus perinteen vaalimisesta ja kunnioittamisesta pitää sisällään 


\section{PertTi Anttonen}

käsityksen joistakin tietyistä sosiaalisista käytänteistä ja arvoista, joihin vaaliminen ja kunnioittaminen kohdistuvat tai joihin sen tulee kohdistua. Vaaliminen ja sen kohde ovat tällöin välittömässä tiedollisessa suhteessa toisiinsa, vaikka kysymys onkin diskursiivisesti tuotetusta yhteydestä. Perinne ilmentää tällöin historiallisen jatkuvuuden arvoa, mutta tällainen arvo saa kollektiivista vahvistusta vain silloin, kun on olemassa vaikutusvaltaisia yksimielisyyttä vakuuttavia argumentteja siitä, mitkä asiat "kuuluvat" olla jatkuvuutta ilmentämässä.

Tässä suhteessa perinne on hyvin valikoiva käsite, mikä puolestaan osoittaa, että perinne on enemmän arvo kuin sisältö - myös silloin kuin sitä määritellään matemaattisin kriteerein. Pitkän ajan kuluessa toistuvat ja/tai sukupolvelta toiselle välittyvät kulttuuriset tiedot, taidot ja ajattelutavat saavat perinteen nimen ja arvon yleisimmin silloin, kun ne koetaan säilyttämisen arvoisiksi, velvoittaviksi ja ylevöittäviksi - tai täsmällisemmin sanoen, kun niistä puhutaan säilyttämisen arvoisina, velvoittavina ja ylevöittävinä. Täsmennys on paikallaan, koska perinteen arvo syntyy juuri puhumisen ja muun argumentatiivisen vuorovaikutustoiminnan kautta. Tällöin perinteiksi nimetyt asiat nostetaan esimerkiksi identiteettitunnusten ja kulttuuriperinnön asemaan, ja sellaisina niille annetaan erityisesti yhteisönmuodostusta ja yhteisönvahvistusta koskeva tehtävä.

Tosin kulttuuriperinnön arvoluokitukseen voidaan nostaa myös ne tiedot, taidot ja ajattelutavat, jotka säilytetään mieluummin arkistotallenteina ja museoesityksinä kuin arkipäivän käytäntöinä. Tämä koskee esimerkiksi agraarista kansanperinnettä teollistuneissa yhteiskunnissa. Perinnettä ei täten vain säilytetä vaan sitä myös säilötään edustavina otoksina ja dokumentteina, tallenteina. Perinteet ovat tässä yhteydessä korostuneesti representaatioita eli perinteeksi luokiteltujen ilmiöiden edustumia, tietoesityksiä ja kuvauksia.

Kulttuuriperintö on modernissa ja erityisesti ns. jälkimodernissa yhteiskunnassa näyttäytynyt lisääntyvässä määrin perinne- tai perintöteollisuutena (beritage industry), tietoisesti tuotettuna kulttuuripoliittisena toimintana ja sen tuotteina. Politiikka-sana viittaa tässä toiminnan tavoitteellisuuteen ja ohjelmallisuuteen, mikä erottaa perinnepolitiikan ns. varsinaisesta perinteestä, jonka ajatellaan välittyvän ilman tietoista, poliittiseksi luonnehdittavaa tavoitteellisuutta. Tämän ajattelutavan mukaan perinnettä on kulttuuri, jolla ei ole tekijyyttä eikä siten myöskään tekijänoikeutta. Kansanperinteen tai folkloren tekijänoikeuskysymyksistä on viime vuosina enenevässä määrin alettu puhua paitsi kollektiivisessa symbolimerkityksessä myös kollektiivisen omistamisen kannalta ja siksi myös juridisin näkökannoin. Perinteen tekijänoikeus on tällöin mitä suurimmassa määrin kulttuuri- ja historiapolitiikkaa; taistelua identiteettiarvon lisäksi kulttuuristen tietojen ja taitojen käyttö- ja jälleenmyyntiarvosta ja -oikeuksista.

Oli perinne ohjelmallisesti tuotettua tai ei, keskeinen kysymys perinteentutkijalle on se, miksi ja miten perinne välittyy. Tai paremminkin: miten ja miksi välittyvät sellaiset kulttuuriset tiedot, taidot ja tulkinnalliset merkitykset, joita kutsumme juuri tuon välittymisen takia perinteiksi. Välittymisen käsite liittyy monella olennaisella tavalla sekä perinteeseen että sen tutkimukseen. Itse asiassa perinteen ideaan sisältyy jo lähtökohtaisesti ajatus sen välittymisestä: perinne välittyy, eli ollakseen perinnettä perinteen on välityttävä ja juuri välittyminen tekee perinteestä perinteen. Puhutaan 
pystysuorasta välittymisestä eli kulttuurisen aineksen siirtymisestä sukupolvelta toiselle sekä vaakasuorasta välittymisestä ikäryhmän tai muun sosiaalisen ryhmän sisällä.

Mutta onko välittyminen perinteen ominaisuus vai onko perinne nimike sille, että välittymistä on tapahtunut? Entä mikä on välittymisen ja säilymisen suhde: säilyykö perinne silloin kun se on välittynyt? Välittyykö suullinen perinne kun siitä tehdään kirjallinen tallenne? Entä silloin kun sen toisto-oikeuksista maksetaan rahaa? Vai välittyykö perinne vain silloin kun perinteentutkija tai joku muu ns. ulkopuolinen hyötykäyttäjä ei ole sitä näkemässä ja siihen omalla merkityksiä tuottavalla katseellaan vaikuttamassa?

Perinteiden välittyminen ei ole aina kulttuuri- tai yhteisöpoliittisesti tavoitteellista, eikä kaikkia perinteitä nosteta identiteettien tunnuksiksi ja yhteisöjen symbolisiksi rakennusaineiksi. Välittyminen ei siten aina ole tietoisen välitystoiminnan tulosta. Tästä syystä perinteentutkimuksen tehtävä onkin kysyä, miksi välittymistä tapahtuu ja miksi sitä ei tapahdu. Miksi jotkut ilmaukset välittyvät laajalti ja toiset taas eivät? Tämä ei ole kuitenkaan vain valintakysymys hyvien ja huonojen perinteiden välillä, vaan vaatii tarkastelun kohdistamista kulttuurisen välittymisen sosiaalisiin, kognitiivisiin ja psykologisiin prosesseihin. Miksi jotkut ajatukset ja ilmaukset tarttuvat ja mikä tekee ne tarttuviksi?

Välittymisen kuvaukset ovat perinteentutkimuksen alalla varsinkin menneinä vuosikymmeninä tukeutuneet metaforiin: esimerkiksi renkaisiin veden pinnalla tai tutkimuksella raivattavaan kasvustoon. Välittymisen selitykset tai luonnehdinnat eivät siis ole välttämättä teoreettisesti pohjustettuja tai perusteltuja. Toisaalta, vaikka välittyminen on suullisen perinteen olemassaolon ehto, kaikki suullisen perinteen tutkimus ei ole välittymisen tutkimusta. Maantieteellis-historiallisesti orientoituneiden folkloristiikan tutkijoiden lähestymistapa kulttuurisiin välittymisprosesseihin oli diffusionistinen eli välittymistä tarkasteltiin kulkeutumisena ja vaeltamisena. Jopa maailmanlaajuisilla vertailuilla pyrittiin paikantamaan folkloren vaellusreittejä kulttuurisista keskuksista periferioihin. Kritiikkinä Kaarle Krohnin mekanistista vaellusteoriaa kohtaan seuraavien polvien perinteentutkijat kiinnittivät huomiotaan yhtäältä vaelluksen puuttumiseen että toisaalta vaelluksen tuottamiin paikallisiin muotoihin ja perinteen sopeutumiseen. Osaksi funktionalismin pohjalta muotoutunut suomalaisen folkloristiikan yhteisökeskeinen paradigma on taasen painottanut välittymisen prosessien sijaan sosiaalista koheesiota välittymisen perustana. Erityisesti Lauri Hongon teorioinnissa on korostunut folkloren ja sen variaation merkitys traditiota ylläpitävän yhteisön sisäisenä viestintänä.

Uudenlaista kiinnostusta välittymisen prosesseihin on kuitenkin havaittavissa. Kulttuuri- tai perinnepoliittinen tarkastelukulma perinteen välittymiseen korostaa arvoperustaisen valinnan ja symbolisen merkityksen diskursiivisen tuottamisen roolia. Perinne on tästä näkökulmasta katsottuna menneisyyden auktorisoimista, sanan kahdessa merkityksessä, tekijää ja valtaa osoittamassa. Muistiprosessien tutkijat ovat puolestaan tarkastelleet muistitiedon skemaattisuutta, muistettavien asioiden jäsentymistä mielessä, sekä muistissa säilyneen aineksen uudelleen tuottamista sosiaalisissa vuorovaikutustilanteissa, esimerkiksi suullisen perinteen esityksissä. Performanssiteoreettisesti orientoitunut tutkimus lähestyy taas välittymistä de- ja rekontekstuali- 


\section{Pertti Anttonen}

saatioprosessien kautta eli tarkastelemalla sitä, miten kulttuurisia tekstejä siirretään metakommunikatiivisesti ja metadiskursiivisesti kontekstista toiseen, puhujan ja tekstin linkittämisen ja sitä kautta muodostuvan yleisösuhteen ja tulkinnallisen viitekehyksen kautta. Meemiteoreettinen lähestymistapa puolestaan haastaa perinteentutkijan pohtimaan sitä, miten kulttuurinen toiminta voi itsessään sisältää oman toistettavuutensa ehdot ja aikaansaada omaa kopioitumistaan. Menneisyydestä johtuvia malleja ei aina seurata tietoisin valinnoin, argumentatiivisin tavoittein tai symbolisin latauksin, vaan asiassa vaikuttavat myös erilaiset hienovaraiset sosiaaliset, kognitiiviset ja psykofyysiset prosessit.

Esimerkiksi uskomustarinoiden toistumisessa ja välittymisessä ei ole välttämättä kyse vain oppimisesta, muistamisesta ja kyvystä tuottaa opittu ja muistettu kertomus uudeksi viestiperformanssiksi. Pelkotilan ilmaiseminen tai jäsentäminen uskomuskertomuksella voi potentiaalisesti välittää uskomustarinaa, mutta välittymisen kausaalisina tekijöinä ei voida välttämättä pitää vain esityksen kuulemista tai samaan uskomisen sosiaalisia funktioita tai sen vakuuttelevaan kuvaamiseen sisältyvää performatiivista sanan voimaa. Kausaliteettia voi olla syytä etsiä myös intersubjektiivisiin tunnetiloihin liittyvistä psykofyysisistä ja jopa hormonaalisista tekijöistä. Monet tekijät vaikuttavat puheilmauksiin ja niiden vastaanottoon, joten ei voida sulkea pois mahdollisuutta, että kertomusten välittymisprosessien ymmärtämiseksi olisi tarkasteltava myös vaikkapa kertojan hikoilua.

Kulttuuriperintökysymysten kannalta välittymisen prosessit koskevat erityisen huomattavassa määrin representaatiota eli kulttuurisen tiedon uudelleen esittämistä, edustamista, lainaamista ja jäljittelyä. Myös perinteentallennus on representaatiokysymys, sillä tallenne ei säilö dokumentoitavaa perinnettä, uskomusta, ajatusta tai puhetekoa vaan tuottaa siitä säilöttävän edustuman. Tällöin olennaiseksi kysymykseksi nousee se, mitä tuolle edustumalle tehdään, minkälaisia tulkinnallisia viitekehyksiä se saa, minkälainen hyödykearvo sille annetaan, mitä tarkoitteita ja tavoitteita se asetetaan palvelemaan, missä institutionaalisissa konteksteissa näin tapahtuu, ja minkälaista representaatiovaltaa niissä käytetään. Erityisen olennaista perinteentutkimuksen kannalta on tarkastella prosesseja, joissa perinnettä ja historiaa otetaan haltuun kulttuurisena omaisuutena. Tarkastelun kohteeksi eivät tällöin nouse vain kulttuurituotteet, jotka näyttävät periytyvän aiemmilta sukupolvilta, vaan myös ne institutionaaliset yhteydet, joiden piirissä periytymisen merkityksiä tuotetaan sekä kulttuurisesta omistusoikeudesta ja jatkuvuuden argumenteista kilpaillaan. Tätä kilpailua ja sitä koskevaa omistusoikeudellista keskustelua käydään nykyisin maailmanlaajuisella tasolla.

Tutkimuksellinen tavoite ei kuitenkaan välttämättä rajoitu tieteelliseen analyysiin eikä varsinkaan kulttuuri- tai representaatiopoliittiseen kritiikkiin. Tieteellinen tutkimus on aina tavalla tai toisella pragmaattisesti motivoitunutta, joten kriittisinkin tutkimus viime kädessä asettuu hyödynnettäväksi vaihtoehtoisissa käytännöissä. Esimerkiksi muistin politiikkaa koskeva muistitietotutkimus ei ole neutraalia tiedettä, jossa tutkijat eivät ottaisi kantaa tarkastelemiinsa asioihin. Sama koskee kaikkea kulttuuriperinnöksi tai historialliseksi perinnöksi määrittyvän henkisen ja aineellisen kulttuurin tuotoksien tutkimusta. Tästä syystä tutkimuksen piirissä onkin syytä käydä keskustelua siitä, millä eri tavoilla perinteentutkimus ja eritoten perintödiskursseihin 
KULTTUURIN, PERINTEEN JA PERINNÖN KYSYMYKSIÄ

kiinnittyvän kulttuuriaineksen tutkimus tekee itsensä relevantiksi sekä tämän päivän poliittisessa päätöksenteossa että tieteen kentässä.

Dos, Ph.D. Pertti Anttonen on folkloristiikan professori (mvs.) Helsingin yliopistossa. 
Pertti Anttonen 
Pertti Anttonen 